\title{
Methods of implementing civil judicial decisions, a study about Jordanian law and Islamic Sharia
}

\author{
Dr. Mashal Mufleh Al-Jarrah', Dr. Kefah Al-Souri², Dr. Ahmad Ababneh ${ }^{3}$ \\ ${ }^{1}$ Assistant Professor, College of Law / Private Law, Amman Arab University.mashallaw @yahoo.com. \\ ${ }^{2}$ Assistant Professor, College of Sharia / kefahalsouri@aau.edu.jo, Amman Arab University. \\ ${ }^{3}$ Assistant Professor, College of Sharia, hamed ababneh@aau.edu.jo, Amman Arab University.
}

\begin{abstract}
Judicial decisions in the law and Sharia are implemented by following two methods, either voluntarily by the free will of the convicted person, or driven by fear of compulsory execution, and it is the second method carried out by the judiciary, by forcing the convicted person to implement the required consequent commitments and cries. The problem of this study lies In the adequacy of the legal texts and Islamic Sharia in finding solutions to implement judicial rulings and decisions, researchers will follow the descriptive and analytical approach, and the comparative approach whenever possible, and the researchers have reached set of results and recommendations, the most important of which was: The forced execution shall be upon legal litigation instated Through the enforcement departments of the judicial authority after exhausting the optional implementation method. As for the most important recommendations, it should be taken into account in the Islamic jurisprudence that the insolvent debtor is considered a debtor who is unable to fulfill his obligations, and not merely the claim of the person convicted of insolvency.
\end{abstract}

Keywords:

execution, forced execution, optional execution.

Article Received: 18 October 2020, Revised: 3 November 2020, Accepted: 24 December 2020

First: The importance of the study:

Judicial decisions represent the plea in bar protection of titles, and that is implemented by issuing rulings by the judiciary to recognize them and taking them into account, but we should note that this protection is minor and inadequate, and therefore it must be supplemented and completed by using operational protection of title and implementing these judgments at the competent enforcement departments and that is through the compulsory enforcement of judgments; In the event that these judgments are not implemented by the voluntary convict by choice, the unenforceable title becomes useless. Therefore, Islamic jurisprudence and the Jordanian implementation law have explained methods of implementing national civil judicial rulings, which is the subject of this study. Second: The problem of the study:
The main problem of the study lies in the adequacy of the provisions contained in Jordanian law and Islamic Shari followed in understanding and assimilation of the various aspects of this topic and the adequacy of the solutions provided by these provisions to the problems and questions they raise.

Third: The questions of the study:

As a response to the main question, which is: what are the methods of implementing civil judicial rulings in Jordanian law and Islamic Sharia?

Several questions arise, including:

1- What are civil judicial rulings and what are the conditions for their implementation?

2- What are the types of enforceable civil judicial rulings?

3- What are the conditions that must be met by a civil court ruling in order for it to be considered enforceable? 
4- What are the methods of implementing civil judicial rulings in Jordanian law and Islamic Sharia?

\section{Fourth: The objectives of the study:}

The study of the methods of implementing civil judicial rulings in Jordanian law and Islamic Sharia aims to achieve many results, the most important of which are:

1- Explaining civil judicial rulings and conditions for their implementation.

2- Determining the types of enforceable civil judicial rulings.

3- A statement of the conditions that must be met by the civil court ruling for it to be considered enforceable?

4- Explaining the methods of implementing civil judicial rulings.

5- Determining the types of forced execution.

Fifth: Previous Studies:

There is no specialized study on the topic (Methods of implementing civil judicial rulings in Jordanian law and Islamic Sharia).

Reference has been pointed in this subject and in some public literature such as Dr. Mufleh AlQudah's book "Principles of Execution", as it deals with the implementation of civil judicial rulings issued by regular courts without referring to Islamic Sharia or taking ot into consideration.

Sixth: Study methodology:

Researchers will follow an integrated methodology to create a clear and comprehensive framework for analysis and comparison in the study of the variety of methods for implementing civil judicial rulings in Jordanian law and Islamic Sharia. The most prominent of these approaches are:

1- Analytical approach: This is done by analyzing the legal text, especially those stated in the Jordanian Implementation Law and any other texts related to the trail/merit, as well as the Sharia provisions, and analyzing these texts and provisions and describing them accurately to clarify the aspects related to the variables of this study and criticizing them.

2- Comparative Approach: The researchers will compare the texts of the Jordanian implementation law with the provisions of the Islamic Sharia related to the subject of the study, as well as the opinions of jurists, judicial discretion and some Arab provisions such as

the

Egyptian Code of Civil and Commercial Procedure whenever possible.

Seventh: The study plan:

In order to answer the various questions raised by the topic of the study, the researchers decided to divide this study as follows:

The first topic: civil judicial rulings and conditions for their implementation in law and Islamic Sharia.

The second topic: Methods of implementing civil judicial rulings in Islamic law and Sharia.

Conclusion: findings and recommendations.

\section{First topic}

\section{Civil judicial rulings and conditions for their} implementation in law and Islamic Sharia

The title is a financial or moral interest that is protected by law and legal protection is considered an element of the substantial title. A title without legal protection does not provide its owner with an interest that is the basis of the title and its essence, since the interest that is a person's connection to certain money becomes a title to grant legal protection to it. The basis of definition of the title, which includes both the interest and the legal protection, and legal protection as one of the factors of the title according to the most likely direction in legal jurisprudence, is available even if there is no violation/aggression on the title, or the title holder gets the benefits and privileges that entitle him to his title in light of the protection of the law ${ }^{1}$. The protection of the title takes place through the

1Wali, Fathi: Forced Execution According to the Group of Civil and Commercial Procedures and the Administrative Detention Law, p. 59. 
issuance of a court ruling by a competent authority that protects what has been requested from the litigants, and accordingly it is necessary to mention judicial rulings/provisions and the conditions for their implementation through the following two claims:

\section{The first claim}

\section{Civil judicial judgment under implementation/execution}

The judicial ruling passes through two phases of the protection phase. The first phase, the judicial protection phase - holding a judgment - is not sufficient to protect titles, and the second phase the implementation of this judgment - achieves the full protection of titles - the legal implementation is: "fulfilling the obligation so that it is evidenced by the debtor's responsibility or is the Abatement of one's title from another" ${ }^{2}$. Muslim jurists defined execution as: "Acting according to the judgment and decreeing it on the convict voluntarily or by compelling the guardian" ${ }^{3}$. So, the law complies with Islamic Sharia in the definition of Execution as it means that the convicted person fulfills what has been ruled by choice or compulsion, and that is when the judicial judgment comes into effect.

The execution of the judgment achieves the congruence between the legal position of the title holder (for whom the judgment has been decided against them) and the effective position of him (actual implementation of what the judgment ruled). The mere fact of obtaining the judgment in itself is of no value if it is not implemented, so it is said that (it is useless to take the floor of an unenforceable right.) This means that the person wins the case

2Shushari, Salah: Compulsory Execution in Civil, Commercial and Legal Articles, Dar Al Thaqafa for Publishing and Distribution, Amman, Jordan, p. 23. - AlZoubi, Awad: The Fundamentals of Civil Procedures, Part Two, First Edition, Wael Publishing and Distribution House, Amman, Jordan, P. 704.

3Jaradat, Ahmad Ali Yusef (2006), The Theory of Execution of Civil Judicial Rulings in Islamic Jurisprudence, Dar AlNafaes, Amman, Jordan, p. 71. twice, once before the trial/merit courts, and once before the execution courts. The person has the right to instate a lawsuit in the trial/merit court-first or second degree court in order to obtain the legal protection for his title/right and his legal position in case of aggression or bring threatened. After that, he shall have the right to implement, based on this right, he can obtain operational protection implementation - of the right or legal position in which the court has ruled his entitlement, by effectively personally enabling him to monopolize the benefits and advantages of the right ${ }^{4}$.

Accordingly, judicial protection differs according to the type and extent of assault, sometimes implemented as soon as a judgment is issued by the judiciary and at other times by another activity by the public authority to re-match the real status of the legal position from the financial point of view to what it was. In these last cases, the legal regulation gives the creditor the right to compulsory enforcement ${ }^{5}$.

The Contentious judgments confirm the substantive right of the difference between other bonds. On the one hand, its composition contains sufficient guarantees to reach the truth, as it is issued by a judge in a judicial dispute, after investigating the facts of the case and its evidence. On the other hand, the law guarantees it a decisive effectiveness in affirming the right through the authentication of the adjudicative order ${ }^{6}$.

The Contentious judgment is issued after reviewing the case and its evidence, and it is issued attached with judicial confirmation of the existence of the creditor's right, which settles every dispute about this right, and the law guarantees the effectiveness of the judgment and its ability to confirm the right

4 -Hindi, Ahmad and Khalil, Ahmad (1999): The Law of Execution, University Press, pp. 5-6.

5Wali, Fathi: Compulsory execution according to the Civil and Commercial Procedures Group and the Administrative Detention Law, previous reference, p. 21.

6 Hindi, Ahmad and Khalil, Ahmad: Forced Execution Law, previous reference, p. 65 
and not allow a dispute about its existence through the authority of the judgment, according to which the judgment is considered the title of the truth. This is in addition to the importance of the judgment as an executive document, and accordingly, judicial decisions are in fact the most common executive document in practical life ${ }^{7}$.

Jurisprudence ${ }^{8}$ defined the Contentious judgments (a document issued by a body with jurisdiction to settle disputes that arise between litigants.)

The Contentious judgment/ judicial ruling is also defined in Islamic jurisprudence as: "What is issued by the judge and those in judicial degree, settling the litigation, concluding the obligation of the convicted person to act or to refrain from an act or to inflict a punishment on the person who deserves it, or to determine the meaning in adequate position"9. The definition clarifies that the Contentious judgment/judicial ruling is represented in obligation, and from the authority authorized to implement and execute the Contentious judgment/judicial ruling, and the issues it includes, such as issues of proof and issuance that take place in the judge's council, establishing capacity, lineage, etc., and the implicit judgment because it is tantamount to reporting as It is concluded from the text of the judicial ruling ${ }^{10}$. If the court ruling is issued proving the right claimed against the convicted person, then it must be executed, Omar bin Al-Khattab said:"for it is not

7Meligy, Ahmad: Usul al-Execution, previous reference, p. 131.

8Tolba, Anwar (2016): The Long Explanation of the Civil and Commercial Procedure Law, 1st Edition, Part 9, Nash Printing Press, Cairo, Egypt, p. 370.

9 Ibn Taymiyyah, Ahmad bin Abdul Halim (1406 AH), 1st Edition, Imam Muhammad bin Saud Islamic University Riyadh, 6/71.

10 previous reference beneficial to give the floor to a right that is not enforceable" 11

Accordingly, the researchers believe that there is an agreement between law and Islamic jurisprudence regarding the importance of issuing judicial rulings to protect rights/titles, and that they are represented in obligation, and they do not arise a right, but rather prove and confirm a right that existed after the case was brought before the judge.

The civil judicial ruling as one of the executive bonds is distinguished by the following:

1 - The executive power of the judicial ruling is carried out by the force of law without issuing any action to impose that power, unlike some executive bonds such as arbitrators' rulings, which require for their execution and by the executive judge.

2- The executive power of a judicial ruling cannot be waived by a ruling, unlike some other executive bonds, such as the contract to open a credit.

3-All disputes related to the executive power of the judicial ruling are raised before the enforcement department or court of case B as required, unlike some other executive documents such as the compulsory arbitration document, so his disputes are not conducted before the execution judge ${ }^{12}$.

Accordingly, not all judgments issued by the courts are subject to compulsory enforcement through the enforcement department, as there are judgements that are ordered to be executed by other authorities as: pre-adjudicated judgments, or non-adversarial judgments, and substantive /considered judgments that are self-executing in fulfillment of all the intention of the plaintiff in his lawsuit, all of them fall outside the scope of judgments executed by the enforcement department; As the pre-adjudicated judgments, such as those that are not lying under the jurisdiction of the court, are enforced by the court's

11bnTaymiyyah, Ahmad bin Abdul Haleem (1406 AH), 1st Edition, Imam Muhammad bin Saud Islamic University Riyadh, 6/71.

12Abraheem, Muhammad Mahmoud (1984): Principles of Forced Execution in the Light of the Legal Approach, Dar AlFikr Al-Arabi, Cairo, Egypt, pp. 125-126. 
refusal to consider the case and refer it to the competent court in accordance with the text of Article (112) of the Jordanian Code of Civil Procedure, as well as the judgment for an expert measure issued, it is enforced accordingly. Likewise the complaint of forgery of the validity of the bond without turning to the original right in the bond, so the judgment issued on it is considered as investigating what the plaintiff intended ${ }^{13}$.

Article 6 of the Jordanian Execution Law No. (25) of (2007) and its amendments stipulated that "Execution is not permissible except with an executive document/bond requiring the right that exists for sure, and specified in amount and the state of performance, and the executive bonds include the following:

A) The judgments issued by the legal, religious and personal status courts and the criminal court rulings related to personal rights and the judgments and decisions issued by any court, council, or other authority whose special laws have stipulated that the department shall undertake their implementation and any foreign rulings that are enforceable under any agreement.

B) Official and ordinary bonds and negotiable commercial paper. $" 14$

13 Al-Qudah, Mufleh (2010): Principles of Implementation According to the Latest Amendments to the Implementation Law - Comparative Study - House of Culture for Publishing and Distribution, Amman, Jordan, p. 50.

14 - Article (280) of the Egyptian Law of Procedures stipulates that “...... and executive documents are judgments, orders, and documents documented and minutes of reconciliation ratified by courts or magistrates councils and other papers that the law gives this characteristic. Execution shall not be permissible in cases other than those exempted by the text of the law, except by virtue of a copy of the executive document bearing the following form of execution) on The authority entrusted with execution may initiate it whenever requested, and the competent authorities must assist in conducting it, even if by using force when requested to do so.

- Article (286) Egyptian code“"“ The court may, in urgent matters or in cases in which the delay is detrimental, order the execution of the judgment according to its draft without announcing it, and in this case the clerk delivers the draft to
Article (2/280) of the Egyptian Procedure Code defined executive bonds as follows:

A- Judgments, including judgments issued by national and foreign courts and arbitration awards.

B- Orders, which include orders on parades/petitions and performance orders.

C- The notarized documents that include official papers that contain contracts or actions.

D- The other documents explicitly authorized by law.

Accordingly, the implementation of judicial rulings at the enforcement departments must meet certain conditions for the ruling in order for it to be considered enforceable, and this will be covered in the second claim.

\section{Second Topic}

Conditions and types of enforceable civil judicial rulings

The legislator stipulated the availability of specific conditions in the civil judicial ruling in order for it to be considered an executable bond, it also specified the types of enforceable judgments. Accordingly, these conditions and types will be indicated through the following Sections:

\section{First Section}

The conditions that must be availability hereby the civil court ruling for it to be considered enforceable. The law requires the availability of two conditions in the judicial ruling in order for it to be considered enforceable, namely:

First: That the civil judicial ruling be among of the executive bonds stipulated by the legislator for example but not inclusively.

Article VI of the Jordanian enforcement Law stipulates the bonds which may be executed and mentioned exclusively, which include the judicial decisions, the orders, notaries deeds and Conciliation ratified hereby the courts or the

the record and the record shall return it as soon as the execution is completed. 
councils of conciliation and other document, that the law gives them this capacity ${ }^{15}$, what matters to us are judicial rulings. The judicial decisions are those of a court formed by law and has jurisdiction and adjudication of all or part of issued or in a matter separate from the original issue.

Second: That the judgment is based on the executive written, a judicial decision may be executed only in an executive writ, i.e. the execution writ, provided for in article 280/3 (was stipulated in pleadings saying, " "Execution may not be permitted in other than cases excepted hereby a provision of the law in the execution writ except under a copy of The executive bond has the execution writ ${ }^{16}$.

Knowing of Executive Bond types shows us what rules, documents, and bonds the law has given us a special force in the implementation process, this force is called the executive force that allows the prevailing party to initiate enforcement action by basing on these bonds ${ }^{17}$.

All of these provisions must be placed on by the execution writ, it is equal in the executive force, i.e. forced execution is carried out on it, but it doesn't equal the force of res judicator, so some bonds are preferred over some. The basis of preference is the results of the bond and its emergence from the

15 - Meligy, Ahmed: Execution according to the provisions of the code of Procedure is attached to it hereby the opinions of jurisprudence and the provisions of cassation, execution, previous reference, p. 194 -. Al-Nimr, Amina (1988) Forced Execution, Maarif Institute in Alexandria, Egypt, p112.

16 Meligy, Ahmed: Execution according to the provisions of the code of Procedure is attached to it hereby the opinions of jurisprudence and the provisions of cassation, execution, previous reference, p. 194. See also Zaghloul, Iskandar (1974), the judge of execution in knowing and Pursuant, Dar Al-Fikr Al-Arabi, Cairo, Egypt, p. 66 - See also Al-Nimr, Amina, Forced Execution, previous reference, p. 112.

${ }^{17}$ Abu Al-Wafa, Ahmad (1991): Execution procedures in civil and commercial issues, 10th Edition, Al Maarif Institute in Alexandria, Egypt, pp. 481 - Shushari, Soliman: Forced Execution, previous reference, pg. 81. judiciary or not the judiciary. So the judicial judgment is the most powerful bond ${ }^{18}$.

Conditions for judicial judgment in Islamic jurisprudence to be considered enforceable.

Muslim jurists stipulated several conditions for judicial judgment to be enforceable, including the following:

First: A judgment based on a genuine litigation on a valid and heard claim, the case should be genuine rather than Dissimulation, if the case is Dissimulation rejected by the judge, for example, for the wife to file a lawsuit against her husband, asking for alimony on her and her children. She agrees with her husband to exempt his money from paying a debt she owes ${ }^{19}$.

Second: The judgment must be binding, this will be applies if the judgment is issued in a strict writ that indicates the binding, such as the judge's saying: It is proved in my opinion that the sum of one thousand dinars for so-and-so and other binding expressions is required. Every word the judge makes is binding, it is considered legal condition and a source for Force and binding ${ }^{20}$.

Third: the judgment must be clear, the judge and the judge must be clearly identified Stare decisis and for it, if the judgment is ambiguous, it will lead to a ambiguities in execution. Therefore, it is not a lift to the dispute between the litigants ${ }^{21}$.

In our view, Islamic jurisprudence has been consistent with the Civil Code in requiring the writing of binding judicial judgment.

18 Ibrahim and Muhammad: Fundamentals of Forced Execution, previous reference, p. 84 -. also, Hindi Ahmad, Khalil Ahmad: The Law of Forced Execution, previous reference, p. 64

19 Jaradat, the Civil Judicial execution Theory in Islamic jurisprudence, p. 166, Yasin, Muhammad Naeem (2003). The Prosecution Theory between Islamic Sharia and the Civil and Commercial Advocate Law, Special Edition, Dar Al-Nafaes, Amman, Jordan, p. 640.

${ }^{20}$ previous reference.

${ }^{21}$ ) Wahdan, Hassan Muhammad (2010), Judicial rulings and methods of appeal thereto, Al-Janadrah Publishing, Amman, Jordan, p. 80. 


\section{Second Topic}

\section{Types of enforceable civil judicial rulings}

Article VI of the Jordanian enforcement Law defines among the executive bonds the verdicts issued by the human juridical courts that may be executed and with reference to the Jordanian Civil Trial Procedure Law as the division of the legal juridical provisions into several sections as follows:

First: Provisions based on subjective defenses and include the following:

a. In terms of the nature of its subjective matter as: civil provisions, commercial provisions, work provisions, guarantee provisions, personal status provisions, penal provisions, and etc.

b. In terms of its function as: Substantive provisions (judicial in the strict legal sense), executive provisions, and Interim arrangements.

c. in terms its subject as: Purely judgments, binding provisions, and judgments constitutive.

Second: Provisions based on procedural grounds, which include:

a. In terms of its authority as: decisive provisions and non- decisive provisions.

b. In terms of its ability to appeal against them in various ways, as: preliminary and final rulings, res judicata, and final.

c. In terms of their issuance in the presence or absence of the litigant, as: default Provisions, absentia Provisions ${ }^{22}$.

Acts of executive power are also divided into judicial decisions, which are the judgments issued by the courts, which include rulings and orders, and non-judicial decisions, which are notarized. There are provisions that are not considered judicial, but are carried out under the supervision of the

\footnotetext{
${ }^{22}$ See Al-Zoaby, civil proceedings code, previous reference, pp. 732-733.
}

judiciary, including the conciliation in hearing transcript ${ }^{23}$.

The legislature also allowed individuals the right to choose arbitrators to make special judgments called arbitrators, which are subject to special rules for their executive power ${ }^{24}$.

Executive bonds are listed exclusively in the Act and the enforcement services may accept the executive of a bond that is not included in and to be measured, because enforcement Forced Execution for the debtor. The legislator in all States is therefore keen to identify $\mathrm{it}^{25}$.

Accordingly, the Iraqi Court of Cassation ruled that the customs decisions to impose fines could not be implemented, because these bonds are not executive bonds hereby the enforcement law or any other $\operatorname{law}^{26}$

The Jordanian court of cassation also ruled (The enforcement Act is mandated to enforce the sentences of all The courts of law, legality and religion, the decisions of the criminal courts concerning personal benefits and the bonds, judgments and decisions of any court. Council or Another authority, whose special laws have stipulated that they should handle them) ${ }^{27}$.

In summary, the types of executive bonds are mainly judicial decisions, arbitrators' judgments ${ }^{28}$,

\footnotetext{
${ }^{23}$ Wali, Fathy: Forced Execution, previous reference, p. 36 -. also, Hindi Ahmed and Khalil Ahmad: Law of Forced Execution, previous reference, p. 64, previous reference.

${ }^{24}$ Wali, Fathy: Forced Execution, Previous Reference, p 36.

${ }^{25}$ Al-Aboudi, Abbas (2007): Explanation of the provisions of the implementation law reinforced by the judicial applications of the Court of Cassation - a comparative study -, Dar Al Thaqafa for Publishing and Distribution, Amman, Jordan, p. 41.

${ }^{26}$ Iraqi Court of Cassation Decision No. 397 / Implementation / 1963 of 10/18/1973, referred to: In -Aboudi, Abbas: Explanation of the provisions of 29 Implementation Law, previous reference, pp. 41-42.

27 challenge for Rights No. 652/1991 Adalah Center Publications.

${ }^{28}$ Shushari, Suleiman: Forced Execution in Civil, Commercial and Legal Articles, previous reference, pp. 81-82.
} 
official bonds, ordinary bonds, negotiable commercial bonds ${ }^{29}$. There are some of the decisions of the Chief Executive, which are executive bonds. the Conciliation organized by the parties to the dispute and approved by the courts. Settlement agreements signed by the parties to the dispute with the mediation Service and ratified by the Judge of the Prosecution Department or the Magistrate are executive bonds ${ }^{30}$.

Types of enforceable judicial rulings in Islamic jurisprudence.

The judicial decisions in Islamic jurisprudence vary with several considerations:

First: In terms of the fact that the convicted person is valid and obligatory to act.

The provision of valid, which has its effects, this type of conduct back to conduct for decades or otherwise, covers all other financial transactions such as selling, renting, mortgaging, lending, borrowing and other transactions. the ruling is valid and the judge is bound by it if the conditions of that alienation are proven to be corrected by someone who owns something The alienator of it, its possession, the competence of the alienator and the validity of the formula for that conduct.

The obligatory ruling according to some jurists is for the judge to authorize the binding of the effects of the alienation , it is not required that the property be proven for the alienator, but rather the competence of the alienator and the validity of the form of that behavior are merely. The ruling is permissible with no requirement to prove ownership of the alienator. Sometimes it is difficult to prove

\footnotetext{
${ }^{29}$ See Al-Mansour, Anis Mansour (2019): An explanation of the provisions of the Jordanian Evidence Law according to the latest amendments is supported by the latest jurisprudence issued by the Court of Cassation, First Edition, Ithraa for Publishing and Distribution, Amman, p. 75 onwards.

${ }^{30}$ Shushari, Suleiman: Forced Execution in Civil, Commercial and Legal Articles, previous reference, pp. 81-82.
}

this, unless it was later found that the owner had not proved and the judgment was overturned ${ }^{31}$.

Second, the division of government in terms of being intentional or implicit.

The meaning of the intentional judgment: which is based on the same claimed right that is required to be adjudicated, as if someone claimed against the last house, established evidence on his claim, then the judge issued a judgment regarding his ownership of this house, so the judgment was intentional. Because it was issued on the same right claimed.

As for the implicit judgment: the judgment is not intended, but is implicitly included in the adjudicated plaintiff, as if the person who filed an alimony claim against her husband and the judge has ruled for her alimony, then the proof of matrimony is an implicit judgment even if it is not subject to dispute, it is required that the intentional judgment be preceded by a valid and fulfilling case, not This is required in the implicit judgment ${ }^{32}$.

Third: The division of provisions according to the means of expression.

The provision is divided into two parts: verbal judgment and the actual judgment.

Verbal judgment: The general principle of the judicial decisions, expressed by a statement from the judge, indicates the obligation as saying: I have ruled, I obligated and other words. There is no specific wording for that.

Actual judgment: Expressed by an act issued hereby of the judge within his jurisdiction; Like buying and selling the orphan's money ${ }^{33}$.

\section{Fourth: The division of judgments according res judicata.}

The judgment divides according res judicata into two parts: judgment due, and judgment invalidity.

\footnotetext{
31 Yassin, Case Theory, p. 661; Jaradat, Judicial Judgment Execution Theory, pp. 39-40.

${ }^{32}$ Yassin, Case Theory, pp. 665-666.

${ }^{33}$ Jaradat, The Theory of Execution of Judicial Rulings, p. 44.
} 
Paying due: If the plaintiff is right in his case, the judge sentenced him. The alleged person claimed the last of his debt and proved him and the judge sentenced him. The defendant to pay the debt, the sentence would be a court of judgment due.

Judgment invalidity: If the plaintiff has failed to substantiate what he has claimed. The judge prevents the plaintiff from going into dispute and confronting the defendant. o this ruling shall be judgment invalidity ${ }^{34}$.

\section{Second Topic}

\section{Methods of implementing civil judicial decisions in law and Islamic law.}

The social necessity for the law to be achieved and implemented is achieved through the effective implementation of its rules in social reality, is no less important and dangerous than the need for the law itself, since a society without a law is equal to a society with a law but does not actually implement it. Legal rules address individuals and are required to respect it. Their respect for it is in the normal course of the matter by their choice. In the conviction of the law, they must respect or fear punishment for the penalties they contain ${ }^{35}$.

The general principle that a person applies legal rules in his or her own free will. For example, in the failure of a person to commit crimes to carry out the crimes, to purchase or sell goods in compliance with the rules of civil law, sometimes the debtor may refuse to apply those legal rules. Here the law is enforced and enforced. This shall be through one

\footnotetext{
${ }^{34}$ Haidar, Ali (2003), Durar Al Hakam Sharh Magazine Al Ahkam, Dar Alam Al Kutub, Beirut, Special Edition, Article 17864 / 573-574.

35 Al-Zoubi, Awad (2019): Al-Wajeez in the Jordanian Code of Civil Procedure, 4th Edition, Lowe Library, Amman, Jordan, p. 21.
}

of the public authorities of the State, which is the judicial authority ${ }^{36}$.

The commitment bond contains two factors: The debt and liability components, and indebtedness is a link between the creditor and its debtor, whereby the debtor is obliged either to perform a particular performance, or to refrain from performing a particular performance. The liability factor is to subject a person or something to the creditor's authority to obtain such performance ${ }^{37}$.

Fulfillment must be done as a general rule by the debtor of its choice, with this fulfillment he is satisfied with the factor of the indebtedness,. If the creditor refuses to fulfill voluntarily, the creditor uses the factor of liability, it obtains performance despite the debtor's will to force, two meaners in the field of civil law: Objective, procedural, and substantive implementation is related to the obligation. It does not have two types of choice (consensual) and is implemented when the sentenced person performs his or her own freely and without coercion from any side. The second is forced execution and the sentence is not satisfied with his or her obligations, this type is done through the enforcement services, ${ }^{38}$ as provided for in the article (9) the Jordanian enforcement Act "the bonds shall not be enforced as long as the appeal is permissible, unless the execution is expedited or governed hereby the law". Methods of enforcement and voluntary implementation will be discussed through the following chapter:

\section{The first chapter}

\footnotetext{
36 Meliji, Ahmad (1996): Principles of Execution in Kuwaiti Law, Part 1, Edition 1, Dar Al-Kitab Foundation 39, Kuwait, p.13.

37 Wali, Fathy (1995): Forced Execution in Civil and Commercial Subjects, Cairo University Press, University Book, Cairo, Egypt, p. 3.

38 Al-Aboudi, Abbas: Explanation of the provisions of the Execution Law, a strengthened comparative study with the judicial applications of the Court of Cassation, previous reference, p. 14.
} 


\section{Optional implementation/execution}

Optional execution is: the convicted person must perform what he committed himself of obligations without coercion and at any time they wish, as the fulfillment may take place before the filing of the lawsuit, after its filing, or even after the issuance of a judgment and implementing it as the matter is already judged ${ }^{39}$. Forcing the convicted to fulfill payment by motivating them by fear of being obligated by the legal regulation,execution in this case is considered an optional execution on the debtor, and the execution is carried out without taking the element of responsibility in the obligation into account ${ }^{40}$.

The optional execution does not have any difficulty or problems, except in the event that a settlement is presented by the convicted person and the prevailing party rejects it and here the prevailing party resorts to compulsory execution.

Consequently, the optional execution is: the convicted person/losing partymust carry out what they were obligated to do in their own volition and without being forced by the public authority to do so.

The Jordanian Implementation Law stipulates in some of its articles the optional implementation, including the following:

1- Article (22 / A) of the Jordanian Execution Law stipulates the following: "A creditor may request the imprisonment of a debtor if they do not pay the debt or offers a settlement commensurate with their financial capacity during the notification period, provided that the first payment under the settlement is not less than $(25 \%)$ of The adjudged sum, and if the prevailing party does not agree to this settlement, the judge may order the parties to be summoned to hear their statements and to

39 - Al-Qudah, MiflehAwad: Principles of implementation according to the latest amendments to the implementation law - a comparative study - previous reference, p. 20.

40Maliji, Ahmad: Principles of Execution Principles of Execution in Kuwaiti Law, previous reference, p.15 investigate the debtor about his ability to pay the sum, and he may hear the creditor's statements and evidence on the ability of the convicted person and issue the appropriate decision.

2 - Article (24) of the Jordanian Execution Law states, "Imprisonment shall be null in the following cases: - If the debtor declares funds that are theirs and sufficient to fulfill the debt."

3 - Article (34 / A) of the Jordanian Execution Law states, "The garnishee/judgement creditor, after being notified of the notification, may repay what he owes by depositing it in the department fund/cash management."

4- Article (38) of the Jordanian Execution Law states, "The creditor/garnishee may keep the attachment until they are requested by the department to return it, and they may deposit it with the department at any time they want before that." 5 - Article (40) of the Jordanian Execution Law states, "If neither the bid nor the deposit is made, the garnisher may enforce the garnishee's funds."

\section{Optional implementation in Islamic} jurisprudence

Execution in Islamic jurisprudence varies to: optional execution and compulsory execution

Optional execution: An obligation may be a duty of religion or a duty of judiciary, so the duty is of religion in Islamic jurisprudence is represented by the normal obligation in the law, and the duty of judiciary in Islamic jurisprudence is represented by the civil obligation in the law, and when we deal with the optional implementation/execution, we mean by it the duty of religion, not of judiciary, because The debtor fulfills his commitments on his own without an obligation or compulsion from anyone, so he responds to the requirement of religion, and as for the judiciary, it is not obligatory to fulfill $\mathrm{it}^{41}$.

Muslim jurists divided optional implementation/execution into two parts: in-kind

41Jaradat, The Theory of Execution of Judicial Rulings, pp. 218-219. 
implementation and corresponding execution with consideration in Islamic jurisprudence.

The first section: in-kind implementation: the jurists use the word "in-kind" in exchange for debt, whether in cash or otherwise, and what is meant by "in-kind" is the present, personalized thing. It could be real estate, offers, cash, fungible items, or weights ${ }^{42}$. The jurists differed regarding the money that can be a debt owed, so money is divided into two parts: real money and properties.

First: The real money is divided into fungible money and value money, so the fungible has been permitted by the jurists to be a debt that is owed, and it is permissible to be lent, so if some of it is owed, the debtor has the right to pay off his debt from it.

As for the value, the jurists agreed that it is permissible to be a debt in assets, and some of it can be described such as jewels. The majority of jurists agreed that this king of money cannot be considered as debt as it's not in-kind or described.

Second: properties, the majority of jurists agreed that properties are valid to be a debt in asset if they are fungible or can be described, as they acquire possession of their assets, which are the objects that benefit from them ${ }^{43}$.

The second section: Execution/implementation with consideration in Islamic jurisprudence and corresponding to it in the law is what is called regular fulfillment. In the event that the creditor and debtor agree to choose the allowance or some of it instead of the original item, if their interest in compensation is achieved instead of in-kind implementation, this is permissible, Provided that this does not lead to usury, and its ruling is the

42(Haider, Explanation of the Judicial Rulers Magazine, article 159) 1/129.

43 Ibn Abdeen, and Al-Sharbini, Shams Al-Din, Muhammad bin Ahmad Al-Khatib Al-Shafi'i (1994), Mughni who needs to know the meanings of Al-Minhaj words, Edition 1, Dar AlKutub Al-Ilmiyya, 162/1, ruling on selling, and what conditions are required for the sale to be valid ${ }^{44}$.

Third: The set-off takes place with the consent of the two parties to the dispute, by dropping the debt you have on your opponent in exchange for the debt owed by him with the same gender and description. $^{45}$

Likewise, in the civil law, the set-off is "to pay a debt required to a creditor for a debt owed to his debtor" 46

\section{The second claim}

\section{Forced implementation/execution}

Compulsory/Forced execution is what is related to our study as it is the method used as one of the means of execution in the event that the convicted person does not respond to fulfill his/her obligation through optional execution, and it is the method that is resorted to in many cases such as collecting debts and therefore, The concept of forced execution and its typesmust be clarified, as it's divided into two branches:

\section{The first branch: Definition of forced execution.}

Compulsory/Forced execution is defined as the execution carried out by the public authority under the supervision and control of the judiciary, based on the request of the convicted person in possession of an executive deed that meets special conditions ${ }^{47}$. In order to fulfill an existing title/right mentioned in a bond of the convicted ${ }^{48}$,this is done by forcing the

44El-Sherbiny, Mughni Al-Muhtaj 1/162 and later, Jaradat, Theory of Judicial Judgment Execution, p. 227.

45 Ibn Qayyim, Muhammad Ibn Abi Bakr Al-Jouzia (1991), Informing the Signatories on the Lord of the Worlds, Edition 1, Dar Al-Kutub Al-Ilmiyya - Beirut, 1/242

46Article (343) of the Jordanian Civil Code.

47Article (6) of the Jordanian Execution Law No. (25) of 2007 states the following: "It is not permissible to execute except with an executive document requiring the existing right and a specified amount and status of performance ...".

48Meliji, Ahmad: Principles of Execution in Kuwaiti Law, previous reference, pp. 19-20. - Al-Qudah, Mufleh: Principles of Execution in accordance with the latest amendments to the Implementation Law - A Comparative Study-, previous reference, pg. 20. 
convicted to fulfill what they are committed to in the event that he does not do so voluntarily.

Forced execution is the execution that is carried out by force on the convicted person and is carried out by order of the judicial authority by the enforcement departments upon the request of the prevailing party, in the event of non-execution voluntarily.

\section{Forced implementation in Islamic jurisprudence}

The basic principle is for the debtor to implement what he committed himself to the creditor, so one of the contracting parties cannot deviate from the inkind execution alone. Execution by compensation is a precaution for execution that is not resorted to except in the event that the actual execution of the obligation is not possible. The jurists agreed that execution shall be started before The allowance, the compensation is not made except in the impossibility of actual execution, and compulsory execution is resorted to when the debtor refuses to fulfill the obligation that his creditor owes, and the creditor demanded the debtor to implement in kind, so when the debtor delays paying what his creditor owes, and he was able, can fulfill the debt in his asset, as the Sharia has offered means for the creditor to enable him to obtain his right and money, and among these means: attendant/concomitant, imprisonment, preventing the convicted person from traveling, and restraint/interdiction of the debtor ${ }^{49}$. We will explain each of these means, including what illustrate them:

First: Imprisonment. The judgment to imprison the debtor is not an implementation of the ruling, but rather a means of pressure to force the debtor to pay off the debt owed by him, if he is able to The Prophet (waid: Delay in payment on the part of one who possesses means makes it lawful to

49Jaradat, The Theory of Execution of Civil Judicial Rulings, pg. 270., Zeidan, Abdel Karim, 2018, The Judicial System in Islamic Law, Edition 3, The Resala Foundation, Beirut, Lebanon, pp. 243-244. dishonor and punish him ${ }^{50}$, and what is meant is that the one who is the one who delays By fulfilling the debt owed by him, the debtor has the right to inform him that he is procrastinating with the fulfillment of the debt and his penalty will be imprisonment; And if the convicted claims his inability to fulfill, and the prevailing party proved the opposite, then the judge shall order the convicted imprisonment until the truth prevails as mentioned in holy Quran "And if the debtor is having a hard time, then grant him time till it is easy for him to repay ${ }^{51 "}$

There are conditions that must be met to imprison the debtor, which are:

A. The creditor's request to imprison the debtor. Debt is his right and imprisonment is a means to obtain his right, and this cannot be achieved without his request.

B. That the debt is current/immediate, there is no imprisonment for the deferred debt.

C. The debtor must be affluent, non-insolvent, and able to pay the debt.

D. Procrastination in paying off the debt that it owes to pay injustice to creditors.

E. The debtor should not be a parent for the creditor; Because God Almighty says: "and to be good to your parents." and it is not from charity that the son imprisons his parents for a debt ${ }^{52}$.

Second: Preventing the convicted person from traveling, the creditor has the right to ask the judge to issue his decision to prevent the convicted person from traveling before he fulfills his adjudicated right, and before the judgment is issued in the case unless the defendant assigns an attorney to litigate and gives a guarantor for what the judge may order for the plaintiff ${ }^{53}$.

50 Al-Bukhari, Muhammad bin Ismael (1422 AH), Al-Jami 'Al-Musnad Al-Sahih Al-Muqtisah of the affairs of the Messenger of God, may God's prayers and peace be upon him, his Sunnah and his days - Sahih Al-Bukhari-, ed.

51 Surat Al-Baqarah: Verse 280.

52Jaradat, The Theory of Implementation of Civil Judicial Rulings, p. 291.

53Zaidan, The Judicial System in Islamic Law, p. 244. 
Third: applying restraint/interdiction on the debtor. If the plaintiff asks the judge to restraint/interdiction the defendant, then the judge verify his financial capacity, and if it is sufficient to pay the debts he owes, the judgment of the convict is to pay the debts. If the convicted refuses to pay, the judge orders his imprisonment, if the convicted could endurethe imprisonment and continues to refuse, the judge shall order to pay the debt from the convicted person's money, and the judge may sell some of his properties if he has money to pay off the debts. If the debts are state and the money of the convicted person does not fulfill the payment of his debts, then the judge shall restrain him at the request of the prevailing party, and the restraint entails matters, including: The judge has the right to sell the convicted person's money to pay off the debt he owed to others. The Messenger of God, may God bless him “restrained Mu'az from his money and sold it to fulfill a debt that he owed" 54 . The judge shall prevent the convicted from dealing with his money if there is a harm for the prevailing party ${ }^{55}$.

Fourth: Concomitant: What is meant is the accompaniment of the creditor to the debtor and companies him wherever he goes, and that does not prevent the debtor from carrying out his work, but rather is a means of implementing the court ruling, as it is a special method only for debts ${ }^{56}$.

\section{The second branch: types of forced execution:}

Forced execution has many types, with a multiplicity of criteria for dividing them, some of which are individual execution, and the aim of it is to satisfy the prevailing party and it is assumed that the convicted person will not fulfill his obligation, and that is by converting a certain money of the convicted person into cash that the convicted person fulfills his debt. Some of them are collective, and

54 Al-Dar Qutni, Ali bin Omar bin Ahmed al-Baghdadi (2004), Sunan al-Daarqutni, ed: 1, The Resala Foundation, Beirut - Lebanon, 5/413.

55Zaidan, The Judicial System in Islamic Law, pp. 244-245. 56Jaradat, The Theory of Execution of Civil Judicial Rulings, 271-275. the aim of it is to satisfy the rights of all the creditors from the convicted person and leads to the insolvency of the convict and thus liquidate the entire convict's liability. An example of this implementation is the insolvency system in the Jordanian insolvency law, which aims to conduct a comprehensive liquidation of the convicted person's liability for the benefit of all creditors and shall be under the supervision of the judiciary, and this execution may be direct (in kind) or indirect (by way of compensation). It may be direct, by resorting to procedures of seizing and selling the debtor's money and requiring the right from its price, and it may be indirect, that is, through seizure and expropriation, these types will be addressed by: ${ }^{57}$

\section{First: In-kind or direct execution:}

If the fulfillment of the obligation is of the principal, that is, if the sentenced person performs the duty of his or her obligation, the prevailing party shall have the right to demand the right to apply for execution in kind, if the losing party agrees to fulfill his or her obligation in kind. The prevailing party shall not resort to a claim for execution by compensation in accordance with the rules of the Civil Code. There is nothing to prevent the simultaneous combination of requests for execution in kind and execution by compensation ${ }^{58}$. In-kind or direct execution is to force the losing party to perform his or her obligation.

In-kind execution (direct) defined as: It is the execution in which the creditor receives the same obligation as the debtor, whether it is an obligation to act, such as the delivery of a particular movable or goods that have unprecedented in the market. The construction of a building or an obligation to refrain from acting. An example of this obligation is not to open a view, not to establish a building, or it

57Meliji, Execution in accordance with the provisions of the Law of Procedures, commenting on the opinions of jurisprudence and the provisions of cassation, previous reference, pp. 13-15

${ }^{58}$ El-Nimr: Amina, Procedural Laws, Book Three, Al Ma'arif Foundation, Alexandria, Egypt, p.9. 
is an obligation to transfer ownership of a particular object or of a kind ${ }^{59}$.

The Yemeni Law of Actions No. 40 (2002) defined the execution in kind of article 348, which is contained in chapter V, called (Subject of Execution), which states that: (The subject matter of execution is exactly what the executor was obligated to do against him in the executive document, whether he was obligated to perform or Doing or refrain from work) ${ }^{60}$.

Execution in kind (direct): it is the object or money on which the execution procedures are to be carried out, whether it is a movable or a real estate, which is originally the losing party to deliver, it is delivered by direct execution. In other words, it is the same as the losing party who has been in the executive authority, whether committed, acting or not, under the debt relationship ${ }^{61}$, if the subject of execution is to receive a certain animal for the prevailing party. The losing did not deliver it. Here the prevailing party receives it by force on behalf of the losing party, i.e. gets the same animal.

\section{- For the validity of in kind or direct implementation procedure, two conditions must be met:}

\footnotetext{
${ }^{59}$ Meliji Ahmed: Execution in accordance with the provisions of the Procedural Law, commenting on the opinions of jurisprudence and rulings of cassation, previous reference, $\mathrm{pp}$. 13-14, see also: Sawy, Ahmad and Al-Ruby, Osama (2005): Forced Execution in Civil and Commercial Matters, Dar AlNahda Al-Arabiya, Cairo, Egypt, P.13.

${ }^{60}$ Al-Jabali, Naguib Ahmad Abdullah Thabet (2014): alwasit in the Forced Execution Law, a study of direct and indirect execution (seizures) according to the Yemeni Law of Procedure, Yemeni Civil Execution and Administrative sequestration, According to the Public Funds Collection Law, Al-Wafa Legal Library, Alexandria, First Edition, p24.

${ }^{61}$ Fathy: Wali, execution according to the provisions of the Law of Procedure, commenting on it with opinions of jurisprudence and rulings of cassation, p. 165- Al-Jabali, Najib: Alwasit in the Law of Forced Execution, previous reference, p. 24.
}

A. Financial impediment does not occur as this becomes the execution financial impossible.

In the event of such an implementation, the obligation cannot be directly implemented, in which case the obligation of the prevailing party becomes a liability for a sum of money as compensation and direct execution is not appropriate. $\mathrm{He}$ also refrained from acting if the losing party committed such an act, despite his obligation to refrain from doing so, in which case the prevailing party had only the right to seek compensation ${ }^{62}$.

\section{B. There is no moral impediment to performing a direct or in-kind execution.}

In other words, implementation is morally feasible, so that the obligation to do so does not infringe upon the personal freedom of the debtor. The losing party may not be assigned to work or refrain from acting, despite his or her will to force him to do so. The property of the losing party in such a situation may not be sequestration, nor liable for any action if the law does not permit it. Only the prevailing party may seek appropriate compensation for the damage suffered and the loss of profits caused by the failure to fulfill the obligation in kind of the losing party judgment before ${ }^{63}$.

\section{Second: Implementation by compensation or indirect execution}

Indirect compensation was defined as: Execution in which the creditor receives a cash payment by the debtor in the event of the in-kind implementation of the original obligation ${ }^{64}$.

${ }^{62}$ Meliji, Execution, Ahmed: Execution according to the provisions of the Procedure Law, commenting on the opinions of jurisprudence and provisions of cassation, previous reference, p. 14.

${ }^{63}$ Al-Nimr, Amana: Procedures Laws, previous reference, $p$. 9. Meliji Ahmad: Implementation according to the provisions of Procedures Laws, commenting on the opinions of jurisprudence and the provisions of cassation, execution, previous reference, p. 15.

${ }^{64}$ - Al-Nimr, Amana: Laws of Procedure, previous reference, p. 9, Meliji Ahmed: Execution according to the provisions of 
Indirect execution or execution by compensation; this is the execution of the judgment by sequestration the losing party's funds and then selling them in public auction and transforming them into cash handed over to the prevailing party, which is the way of implementing the obligation that is instead of money; Because he is not directly concerned with money, but with a transfer or property owned by the losing party, which is held on behalf of the sentenced person. Then sold and received the prevailing party his right from its price, because the prevailing party, is entitled to him when executed it on property or movables of the convicted person, it affects other rights owed to the losing party. As the subject of execution is not the subject of the obligation, but the money of the losing party ${ }^{65}$.

Indirect execution, meaning execution of the money of the losing party or by means of reserving, is only in the case of an obligation to pay a sum of money, regardless of the obligation. Whether it was originally payment of a sum of money or that it became so after the obligation became an obligation to pay for any through Compensation as a result of the inability to execute it directly, because of moral incapacity such as the loss of the committed property, the occurrence of the committed act or a moral incapacity such as the impossibility of force against the losing party to perform the committed act. In the indirect execution, the sentenced person does not receive his right directly, but he is also held in possession of any money of the prevailing party by selling him in public auction to transfer it to his right money ${ }^{66}$.

the Law of Procedure is suspended by the opinions of jurisprudence and provisions of cassation, implementation, previous reference, p. 15.

${ }^{65}$ Al-Zoubi, Awad: Fundamentals of Civil Trials, previous reference, p. 706.

${ }^{66}$ Meliji, Ahmed: Execution in accordance with the provisions of the Procedure Law, commenting on the opinions of jurisprudence and the provisions of cassation enforcement, previous reference, p. 15
This shall be in accordance with the general rule that any money of the debtor may be held in the sequestration of the debtor, as a result of the general guarantee provided by law under which the financial security of the losing party shall be the general guarantee of the prevailing party. However, there is no money for the prevailing party person who cannot be held in reserving, because of a range of considerations created by the law. The law excludes certain funds from the scope of execution, it is not valid to be a subject, if such funds are reserved, the law is invalid ${ }^{67}$. As the Jordanian enforcement law stipulates in article 29. From him on " the following things cannot be sequestrated:

A. The necessary clothes and furniture necessary for the debtor and their legal dependents.

B. Cooking and keeping pots and food pots for the debtor and his family.

C. Books, instruments, tools and pots to practice his profession or trade, unless the debt is in present.

D. The necessary supplies for the debtor and their legal dependents.

E. Seeds to sow the land of the debtor that it used to plant, if it was farmer.

F. Animals necessary for the debtor's life and for the cultivation of land, if it was farmer.

G. Feed animals that are excluded from the sequestration, which will last for a period not exceeding the seed season.

H. a uniform for government employees and their other official supplies.

I. Alimony, clothing, and church tools that are used for worship.

J. Alimony.

\section{Conclusion}

(Results and recommendations)

\footnotetext{
${ }^{67}$ Al-Jabali, Naguib: Alwasit in the Law of Forced Execution, previous reference, pp. 24-25.
} 
After studying the methods of implementing the civil judicial decisions, a study in Jordanian and Sharia law, researchers have reached a number of results and recommendations:

\section{First: Results}

1. Islamic jurisprudence has preceded all contemporary positive laws in the statement of the methods of implementing judicial decisions.

2. The law agreed with Islamic jurisprudence that judicial decisions were binding, proving and asserting a right that existed after the case was filed with the judge, and it don't affect.

3. There are two types of execution, compulsory execution and voluntary execution, stipulated by law and Islamic jurisprudence.

4. Recourse to enforce execution is through the executive authority according to a lawsuit filed before the judiciary through the enforcement departments of the judicial authority, after the consensual execution method has been exhausted.

\section{Second: Recommendations}

1. Researchers hope that the Jordanian lawmaker will restrict the debtor's freedom as a means of execution, as stated in the Islamic jurisprudence, through the means of binding, in which the legislator sets a system for this means, in which he shows how it binding and when it is used.

2. Researchers hope that the legislator will take into account what was stated in Islamic jurisprudence regarding the insolvent debtor, as being the debtor who is unable to fulfill his obligations and not merely the claim of the convicted person for insolvency.

3. Researchers hope that the Jordanian legislator will not resort to any mean of implementation, unless the document or judgment to be executed is appended to the executive formula. 